\title{
GASTRONOMIC TOURISM IN THE CENTRAL BOSNIA REGION
}

\author{
Amra Banda ${ }^{1}$ \\ Aida Korjenić2 \\ Aida Avdić ${ }^{3}$
}

\begin{abstract}
The attractiveness of food, especially national, is one of the predispositions for developing certain forms of tourism: rural, ecotourism, gastronomic and enogastronomic tourism whose focus is food that is healthy and organic. Although food is not a basic tourist motive for many tourists, there is an increasing trend of manifestation tourism and food festivals, where gastronomy is the central or accompanying motive. Valorisation of gastronomic tourism in the Central Bosnia region is at a very modest level. There is no significant interest in the development of this form of tourism in the region by tourism organizations, but also by local and cantonal authorities. First of all, there are no systemic incentives for the population to develop gastronomic tourism in rural households and for the presentation of traditional products to visitors. Also, there is no interest of the professionals in the field of tourism and cuisine arts for developing strategies and modules for improving the gastronomic supply.The Central Bosnia region has great potential for organic production because of its unpolluted land, climate and numerous agricultural producers, and traditional farming has led to final products that can represent national, regional and international brands. The main goal of this paper is to identify the leading gastronomic potential that the research area has and to point out the necessity of putting them into the function of developing certain aspects of tourism.
\end{abstract}

Keywords: gastronomy, tourism, Central Bosnia region, Bosnia and Herzegovina

\section{INTRODUCTION}

Gastronomy represents a very important segment of a tourismsupply of a country. Terminology used in literature when referring to this type of tourism is very different: "gastronomic tourism", "culinary tourism", or "eno-gastronomic tourism" (JiménezBeltrán, J.et al. 2016). All these terms express the intention of knowing other culturesthrough its typical food, in order to obtain unique and memorable gastronomic experience (Vulić, 2006). Food and gastronomy also make a significant contribution to the sustainability of a particular area. The most significant local resources based on development are divided into two dimensions: the environment and the people. The specific environment is considered by the economic characteristics of a significant area occupied by local agriculture or food (Rinaldi, 2017). The dimension of people is described as a community belonging to different types of occupations: farmers, food producers, food processors, chefs, tourist planners, authorities, local people. They all cherish local customs and heritage that are the source of identity and contribute to authenticity (Tešanović, Banjac, Kalenjuk, Tošić, 2018). Gastronomic products in a

\footnotetext{
${ }^{1}$ Senior Teaching Assistant, Department of Geography, Faculty of Science, University of Sarajevo, Zmaja od Bosne 33 - 35, 71000 Sarajevo, amra.banda@pmf.unsa.ba

${ }^{2}$ Associate Professor, Department of Geography, Faculty of Science, University of Sarajevo, Zmaja od Bosne 33 - 35, 71000 Sarajevo, aidakorjenic@yahoo.com

${ }^{3}$ Teaching Assistant, Department of Geography, Faculty of Science, University of Sarajevo, Zmaja od Bosne 33 - 35, 71000 Sarajevo, avdic.aida@yahoo.com
} 
tourismsupply take precedence over other services. They represent specific physical, material products with a defined shape, color, texture, taste, smell and can be stored and saved, unlike services that have no physical attributes and which tourists can not carry with them.

With the development of contemporary tourism, gastronomic tourism is increasingly evolving, which is primarily defined as visiting tourists of primary or secondary food producers, food festivals, catering establishments for food production and certain serving destinations for tasting and / or experiencing the attributes of regional specialties where food is the primary motive for travel. Kalenjuk, Tešanović and Škriljar (2011) consider that gastronomic tourism could be defined as the activity of research and discovering culture and history over food, which influences the formation of unforgettable experiences.Fields (2002),determined that the type of motivation associated with gastronomic tourism is of vital importance and identifies four possible motivations based on the physiological needs that everytraveler must cover, relating, in most cases, to some type of restaurant. These are: physical motivations, directly related to the aforementioned need to eat; interpersonal, which are directly related to the social nature of people; cultural, which regard the desire for knowledge of other cultures and places; and the motivations of status, focused on the recognition of a particular social prestige or distinction sought.

According to the World Food Travel Association (WFTA), gastronomic tourism is the act of traveling for a taste of a place in order to get a sense of place ${ }^{1}$. Given that food is a component and characteristic, part of the tradition and history of a nation, it is an important part of the basic cultural tourism motives, which are labeled as ethnological. The aim of the tourist is, among other things, to acquaint the specificity of the culture, tradition, natural and cultural attractiveness of the visited area, but also to try out local gastronomic specialties. The traditional culinary region of Central Bosnia is the culinary art of the people of this area, built on the elements of the Bosnian-Herzegovinian culture with a significant overlap of the elements of other cultures that have changed in the past in this area. The history of nutrition in the region of Central Bosnia can be traced back to the ancient times of classical Rome and Byzantium through the mediveal Bosnian state, the Turkish and Austro-Hungarian period to the modern times of the XX and XXI centuries. Specific notes of this area give the eating habits that have their base in Islamic, Orthodox, Catholic and Jewish religion.

Gastro tourists visit certain areas primarily for tasting food and beverages specific to the area. The development of gastronomy in the Central Bosnia region can contribute to the development of its overall tourism supply. The advantages of the development of gastronomy are reflected in the creation of a complete and high-quality touristic product, in improving the overall tourismsupply through the development of tourism inside and outside the main tourist season (especially in the spring and autumn) and in promotion of a unique image of the destination at the international level.The development of gastro-tourism stimulates the development of rural areas. It also motivates entrepreneurship, employment and self-employment and it has an important role in preserving the authentic ambience, culture and tradition, and in the placement of domestic products for vineyards and farmers.

${ }^{1}$ https://www.worldfoodtravel.org/cpages/what-is-food-tourism - accessed February 06, 2019 
Although it has a tendency for development and great potential, the Central Bosnia region still has poorly developed rural and gastronomic tourism. Following activities should be taken,in order to improve gastronomic tourism in this region:

- $\quad$ to develop a range of typical organic gastronomic products

- to work on preserving local specialties, products and recipes,

- $\quad$ to organize thematic gastronomic and culinary events,

- to present a gastronomic supply through domestic airlines who would offer specialties and products in airplanes

- $\quad$ organization of herbal medicinal herbs and forest fruits in rural areas with educational workshops and

- to provide opportunities for tourists to participate in the preparation of gastronomic specialties specific for the region.

Labeling gastro products of this region, which could become recognizable at the regional and international level, is a particularly important step. Products withspecific geographical origin have developed market world wide and are popular among tourists, which is a great development opportunity for gastronomic tourism in Central Bosnia.

\section{Geographic location of the Central Bosnia region}

The Central Bosnia region occupies the area of central and eastern Bosnia and Herzegovina, capturing parts of the catchment areas of the rivers Pliva, Vrbas, Bosna, Lašva, Krivaja and Drina.(Figure 1).It covers an area of $13.037,89 \mathrm{~km}^{2}$ or $25,5 \%$ of the total area of Bosnia and Herzegovina.The altitude of this area ranges from $500 \mathrm{~m}$ in the valleys, up to $2.366 \mathrm{~m}$ - the largest peak of this region and in Bosnia and Herzegovina, mountain Maglić. Climatic characteristics of the investigated area are reflected primarily by the given geographical location and hypsometric relations of the relief, on the basis of which this area is under the influence of a moderate continental climate (moderately warm and humid climate with warm summers or Cfb climate according to Koppen's classification) and the mountain climateis represented at higher hypsometric levels (Drešković, Mirić, 2017). When it comes to hydrographic characteristics of the Central Bosnia region, the largest rivers Pliva, Vrbas, Bosna, Lašva, Krivaja and Drina with their tributaries make up the river network of this area. The well-developed river network and favorable climatic conditions were the basis for the early settlement of this area, as well as for the emergence of migration routes which people used for moving during the century and bringing different cultures and customs. Favorable pedogeographic characteristics contributed to the above. The fertile automorphic soil, distric cambisol on acid silicate rocks, calcocambisol (brown soils on limestone), humus accumulative soils - calcomelanosol (limestone dolomite black), luvisol, humus accumulating soil of rendzin and the complex of lithosol-rendzine on dolomite, and with a slightly lower proportion of hydromorphic, fluvial soil (fluvisols), which were the basis for agricultural production and cultivation of different types of plant crops.

Also, the mountainous character of the area was favorable for the development of fruit and cattle breeding. Great diversity, especially when it comes to ichthyofauna is one of the characteristics of this region. The rivers have significant amounts of salmonid and cyprinid fish species. 
According to the administrative and territorial position, this region is part of the entities of the Federation of Bosnia and Herzegovina (50,6\%) and Republika Srpska (49,4\%). It covers parts of four cantons within the bigger entity, while at the local level it consists of a total of 44 municipalities in both entities.

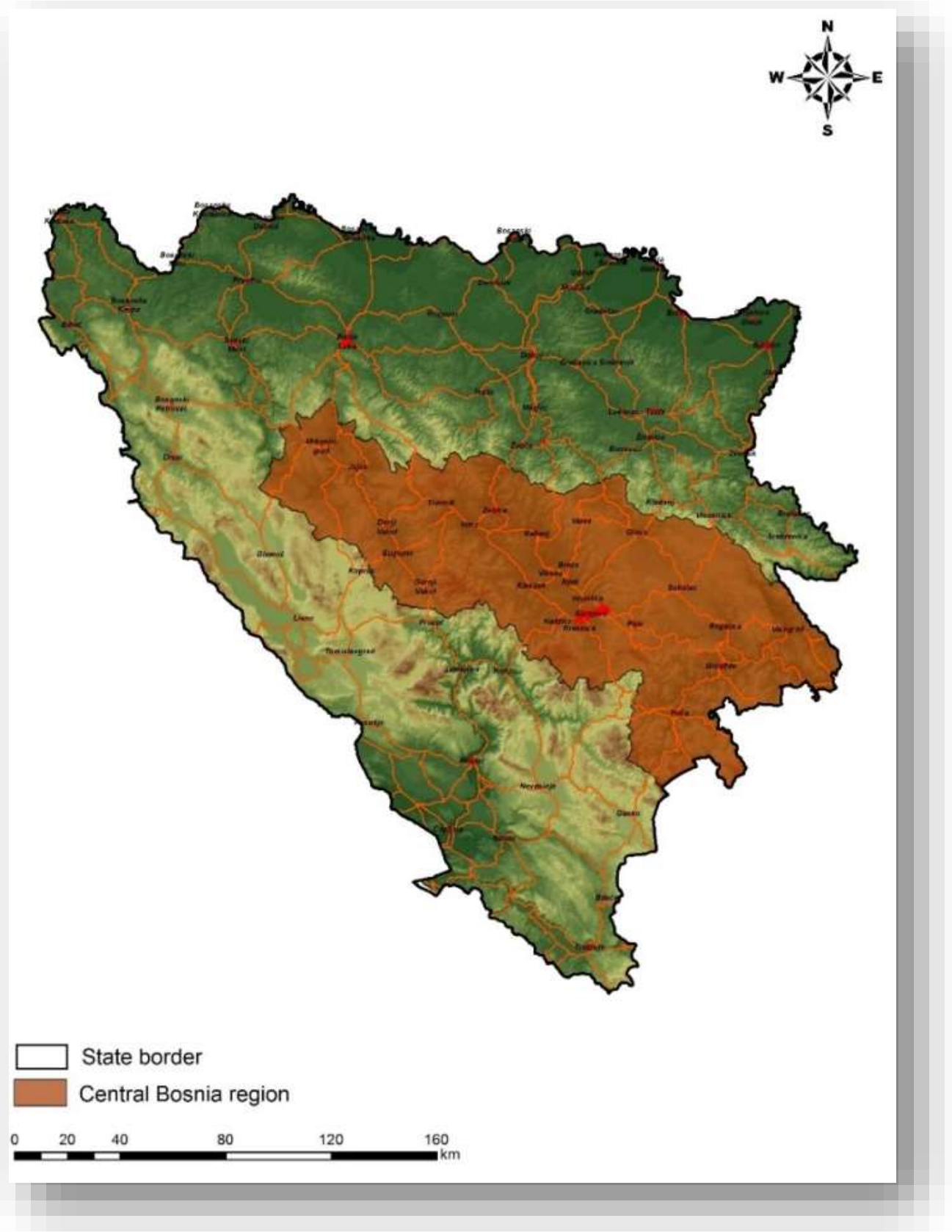

Figure 1. Geographic location of Central Bosnia Region 
The population dynamic is one of the important demogeographic indicators that condition the socio-economic development of the given area. In addition to data from 1991, as the last pre-war census, data on the number of inhabitants from the 2013 census is also used. Based on these data, it can be noted that between the two last censues, the number of inhabitants increased in urban areas and decreased in rural areas, especially in the eastern parts of this region. Declining population density is characteristic of both the region and the whole country.

The general population density in 1991 was 106,7 inhabitants per kilometer square, while in 2013 the value of this demographic ndicator was 81,8. However, within this region due to the diversity of natural-geographical conditions, the population is dispersed. In those parts of the region where the natural-geographical conditions of the settlement were more favorable (valleys and basins), the population and concentration of the population is higher, and where the natural-geographic conditions were less scarce (mountanious areas), the population and concentration of the population is less. According to the 1991 Census, the Sarajevo - Zenica basin is the most densely populated area of Bosnia and Herzegovina with a population density of 176,4 inhabitants per kilometer square, where in the area of 11,4\% lived almost the quarter of the total population of Bosnia and Herzegovina. The mountain area (Gornjodrinska subregion) is a part with the lowest population density, which is way below state average. Central Bosnia region has a population of 1.060 .716 , which is $30 \%$ of the total population of Bosnia and Herzegovina. The highest population is in municipalities of the City of Sarajevo, while the smallest is in the municipalities in the east and southeast of the region (Trnovo, Foča, Čajniče, Rudo, Višegrad, etc.).

Economic structure is one of the most significant population structuresin social geographic research, where the share of active and dependent population is a specific indicator of the economic development of a given area. The economic and geographical position of this region is extremely favorable because it occupies an area rich in mineral resources, forest capacities and etc. The most developed area of this region is the Sarajevo-Zenica basin with the main center of Sarajevo, which is also the capital of Bosnia and Herzegovina.

Regarding the traffic situation, Central Bosnia region is located in the very center of Bosnia and Herzegovina, and through it all major traffic routes pass.

Part of the highway $\mathrm{Vc}$, the developed network of main and regional roads, railway traffic, and the nearby international airport in Sarajevo are just some of the predispositions for the development of all types of tourism, as well as the development of gastronomic tourism in this region.

\section{METHODOLOGY}

The principal aim of this paper is to identify the leading gastronomic potential of the study area of Central Bosnia Region. Also, one of the goals is topoint out necessity of including gastronomy and the existing food fairs into tourism supply. Direct survey was conducted among tourists visiting the region of Central Bosnia and tasting typical dishes in the culinary establishments characteristic of the area, aiming to know their motivations and levels of satisfaction based on different aspects that influence them, as well as on the concept of local cuisine. 


\section{ANALYSIS}

\section{Gastronomic supply of the Central Bosnia region}

Author who analyzes the close relationship between the culinary experience and the levelof satisfaction obtained is Babolian Hendijani (2016), who considers the ingredients and products usedin the preparation of the dishes (fresh and of quality) as the cultural and gastronomic heritage of theplace, and at the same time as a catalyst. Stone et al. (2018), conclude that positive culinary experienceson a trip often result in positive memories.Bjork and Kauppinen-Raisanen (2016), analyzed the role of the gastronomic experience and the tasted product as a sufficient reason to travel, as a decisive element, or as an added and global satisfaction of the trip. They determined three types of visitors; (I) experimenters, whose primary motivation is to gain local culinary experience when traveling; (II) tasters, for whom local food represents a valuable and positive aspect; and (III) survivors, for whom the act of eating does not represent an added interest or consideration.Acording those authors, gastronomy represents a crucial factor in decision making for a tourist destination, based on the different attitudes shown by tourists.

Traditional dishes are considered certain dishes that are stored for a long time in a certain area, and have become a characteristic of tradition. Since many nations have brought their culture, customs, and the way of preparing food in these areas, it can be concluded that the traditional cuisine of the Central Bosnia region refers to meals and cooking skills that fill the menu for a long time in this part of Bosnia and Herzegovina regardless to their origins.

\section{Indigenous dishes}

Typical dishes of the Central Bosnia region are varieties of soup, pies, meat dishes from barbecue and barbecue, sarma and dolma, kalja, musaka, pirjana, pilav, bread, dishes from various types of milk and dairy products, dishes and products of fruits and vegetables, salad etc.These are the general names of the dishes, but each name belongs to a specific number of subtypes of food which are often characteristic of certain areas in the Central Bosnia region.

Soup/broth - an appetizer or a standalone meal. They are prepared quite thickly and usually with pieces of meat, vegetables or paste and with a lot of parsley.Some of the most famous types of soups in this area are: begova (Error! Reference source not found.), višegradska, sarajevska, trahana, cabbage soup and others.

Pies - an indispensable part of Bosnian cuisine. Pies can be sweet and savory, prepared from meat, vegetables, dairy and fruits. Typical examples are: burek (stuffed with chopped or minced meat) (Error! Reference source not found.), sirnica (with cheese), krompiruša (potatoes), zeljanica (with spinach or chard), tikvenjača (stuffed with pumpkin) which are made with the crust of the dough as thin as paper and then shaped into circles and parallel strings. Other sorts of pies, like kljukuša, ljevača, razvaruša, furdenjačaare made by placing the dough together with the stuffing in a bowl.

Grilled and grilled meats - lamb on a spit, pork on a spit, veal prepared in sač (traditional baking dishes), skewers, burgers. The most famous arećevapi - shredded meats,especially ćevapi made in Sarajevo and Travnik, šiš ćevap and hajji ćevap. 


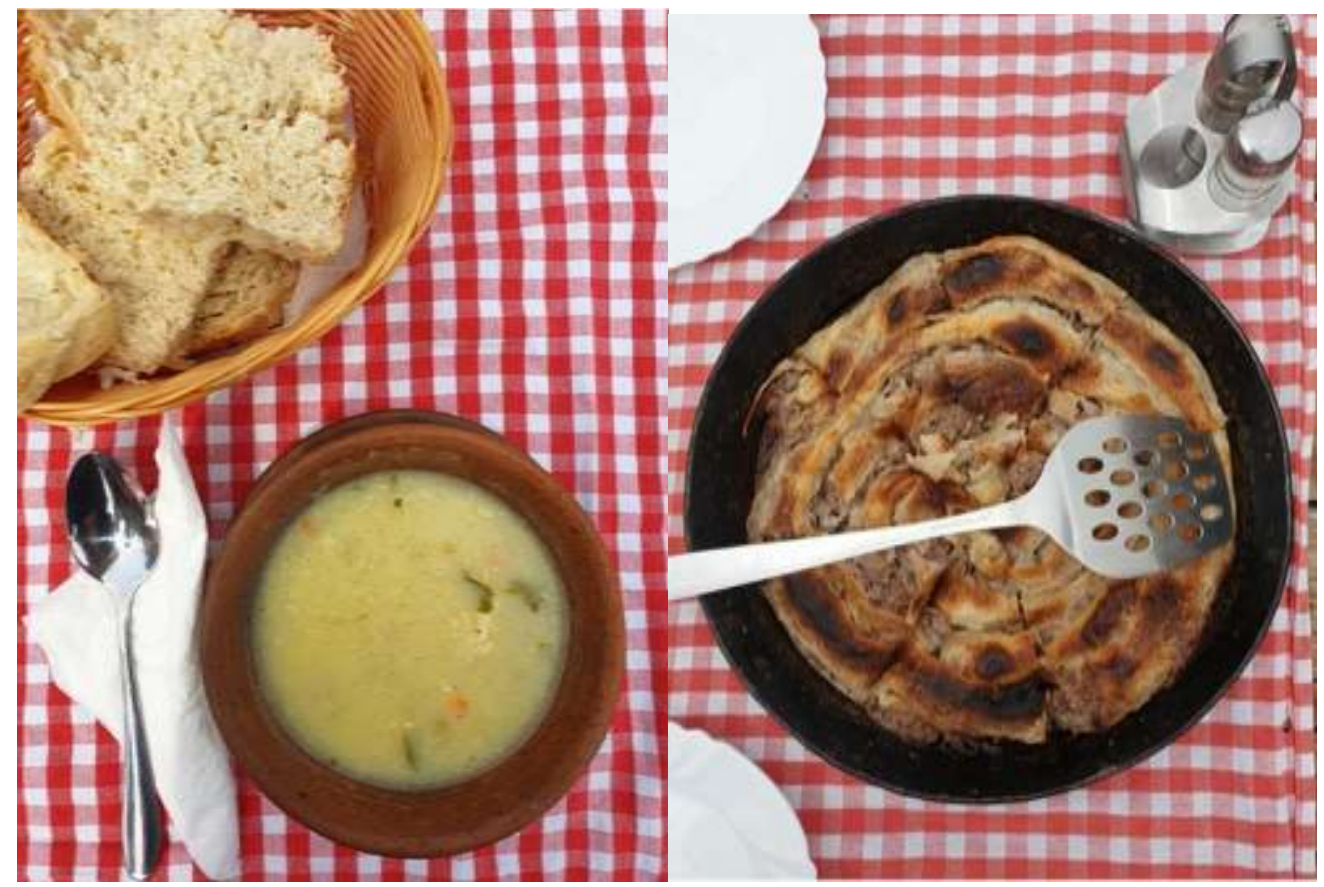

Figure 2. Indigenous dishes of Central Bosnia region

Dolme and sarme - are dishes prepared from minced meat and rice that fill certain vegetables, such as: sogan dolma, zucchini dolma, sarma, japrak, etc. Sarma is characterized by the fact that the stuffing is wrapped in cabbage leaves, young vines or roasts.

Kalja - cooked vegetable and meat dish with the addition of kajmak. It can be made of potatoes, cabbage, beets, etc.

Musaka - a mix made of some vegetables and meat. It can be made of: potatoes, pumpkins, eggplants, pods, kale and others.

Pura - a dish that is made from corn flour, served with sweet milk or cream and butter. Different types of breads - lepina, somun, pogača, proha poležaka.The Bosnian bread is known historically - the bosman, which was made during the Austro-Hungarian Empire. It was made by women to young men who went to war in the Austro-Hungarian army. This bread could be used for a long period of time.

Topa - a characteristic Bosnian appetizer based on melted fat, to which various types of cheese, cream or eggs can be added.

Sweet dishes - there are many of them, but baklave, tufahije and hurmašice, ružice, đunlari, gurabije, halva, šape, plum pie, rešedija, lokumi, kadaif, ćetenija and many others stand out as characteristic. Tufahija is considered to be the only traditional cake made in the territory of Bosnia and Herzegovina, while others are taken from other cultures and people who immigrated to this area (Lakušić, 1999).

Zahlade - treats that are prepared on special occasions such as: zerde, muhalebija, višnjab, alasija, ašure, sweet cream with honey, pelte - paluza, hošaf and others. Paluza is a typical Bosnian delicacy, where apple jam is used instead of sugar. 


\section{Traditional agricultural food products}

Due to the extremely favorable natural-geographical factors and livestock potential some parts of the Central Bosnia region have become recognizable for their milk products from cows, sheep and goats.

The quality and composition of milk products, in addition to originating from indigenous breeds, undoubtedly lies in the uniqueness of the diversity of plants in the rich pastures of the region. The region is known for producing various types of cheeses such are Vlašić/Travnik cheese, smoked cheese, kajmak, Prokoško cheese, mlaćenica, cowbutter etc. Fat cheese is traditionally produced in Eastern Bosnia, around Čajniče, Tjentište and Sokolac.

All the mountainous areas of this region prepare Urdu cheese, and in Eastern Bosnia the other type of cheese is called Zarica. Travnik (Vlašić) cheese is one of the white cheeses in brine and is in the better known group of cheeses called Feta. It is made mainly in a mountain in cheese huts where it is stored for 2-3 months to mature.Different breeds of domestic animals that have been brought to the area in the past have over time acquired the characteristics of specific ecotypes, and today they represent differentiated and even isolated forms in the general gene pool of domestic animals. Variety is present in breeds of cattle, sheep, goats, pigs and horses.An indigenous breed of cattle is called buša, sheep - pramenka, goat - balkanska rogata, pig - šiška. Salt and smoked meat products are distinguished as specific: Bosnian sudžuka, suho meso (smoked meat) - (especially in Visoko) and others.

Also, this region has extremely good climatic and pedogeographicalconditions for growingvarioustypes of fruits and vegetables (Table 1), and the population has been preparing products since ancient times such as various types of jam from indigenous varieties of apples, pears, plums, cherries, rosehip and others. Dried pumpkins, dried peppers and various types of pickles (from cabbage, cucumbers, tomatoes, peppers, beets and mixed vegetables) are also characteristic. Recently, demand for eco produced fruit is increasing.

The various types of fruit, thick juices (diluted with water - šerbe) and squeezed (100\% fruit) juices, used in the fresh state, are also traditionally prepared and can be preserved.Besides apple juice, apple cider vinegar is also made.Brandy, called rakija derived from fruits (apples, pears, plums, etc.), as well as wine and liqueurs are especially distinguished as traditionally.

Honey is very often used in kitchens of almost every household. Bee grazing is performed at altitudes of $300-1.500 \mathrm{~m}$, in an area rich with honey plants without any contaminants, so this honey is known for its quality.

Vegetables that stand out in particular are: pumpkins, beans (ćućo, bubnjo, trešnjo), peppers, okra, and potato varieties (from Romanija, Fojnica, etc.).One of the interesting activities related to gastronomy is mushrooming. The mountains of Central Bosnia region are rich and best researched habitats of mushrooms in Bosnia and Herzegovina. In the municipality of Mrkonjić Grad over 1.300 species of fungi have been found over the last 20 years. ${ }^{1}$

\footnotetext{
${ }^{1}$ Mrkonjić grad - turistički vodič, Udruženje za razvoj i unaprjeđenje turizma i općine Mrkonjić Grad - Mrkonjička kapa, 2010. str. 32-34.
} 
Table 1: Overview of Somelindigenous Fruit Varieties in the Central Bosnia Region

\begin{tabular}{llll}
\hline Apple & Pear & Cherry & Plum \\
\hline Senebija & Jeribasma & Karaašlama & Bosanka \\
Hajvanlija & Huseinbegova & Crvene ašlame & Kaurka \\
Petrovača & Buzdohanlija & Bijela ašlama & Ružica \\
Sadićka & Kolaćuša & Hršut & Slatkulja \\
Pamuklija & Kantaruša & Bosanlija & Smokvica \\
Ramićka & Mednica & Azijatka & Prskulja \\
Samoniklica & Brdenjača & Divljaka & Dinka \\
Hodžićka & Begamuta & & Bjelošljiva \\
Zuja & Zimnjača & & \\
Kanjićka & Korajka & & \\
Lozika & Batva & & \\
Šećerka & Miholjka & & \\
Ledenica & Karamut & & \\
Grehotulja & Beglija & & \\
& Pljuska & & \\
& Takiša & & \\
\hline
\end{tabular}

Source: Northeaste regional development association ${ }^{1}$

\section{Gastronomic events and fairs}

In the Central Bosnia region, more and more events have recently been organized where food is a basic tourist or accompanying motif. In this case, food and activities related to food - gastronomy, are presented as special or very significant features and values of the interest for the event.In the text below is an overview of gastronomic events organized in the municipalities of the region.

In the municipality of Mrkonjić Grad fourgastronomicevents are organizedduring the year: The main goal of these events is to promote local products through tasting and education, with a rich cultural - entertaining and professional program. The local brandy festival, Ethno festival "Jabuka" and „Dani meda“, takes place in the winter. The last one was held in November 2018, which brought together about 70 exhibitors from Bosnia and Herzegovina. Various types of local brandy, folk handicrafts, honey, propolis and traditional dishes were on at the stands. Four expert lectures were also held during the event.

Apart from these, there is a characteristic manifestation called „Dani gljiva“. The aim of the event is to exhibit mushrooms, medicinal herbs and education. It takes place on the last weekend in September on mountain called Lisina.

Although not entirely a gastronomic event, until 2012, an event called „Dani zdrave hrane, ekologije i turizma" (Healthy Food, Ecology and Tourism Days) was organized in Jajce. The aim of the event was to present local, healthy food, domestic products as a tourist potential and to promote Jajce as a gathering place for healthy food producers in this region.The occasion also featured the rich cultural heritage and diversity of

${ }^{1}$ Zaštita izvornosti, geografskog porijekla i tradicionalnog ugleda u prehrambenoj industriji, Northeaste regional development association, Tuzla, 2009, str. 15. 
Bosnia and Herzegovina by promoting traditional dishes, music, games, folk costumes and handicrafts.During the event, special attention was paid to a public campaign aimed at raising awareness of the need to use and produce local organic products.Since 2014, the STEP - Sajam turizma i eko proizvoda (Jajce Tourism and Eco Products Fair)has been held in this municipality. The Tourism and Eco Products Fair officially opens the tourist season, and in 2018, over 50 eco-product manufacturers from all cities in our country, as well as abroad, representatives of travel agencies and tour operators, hoteliers and caterers, gathered at the Fair.

EverySeptember for the past sevenyears, a fair of agriculture and eco-tourism has been held in Bugojno called"Zlatna jesen" (GoldenAutumn)-The aim of the fair is to send a message to the public that a healthy environment and organic food production can be the key to job creation through self-employment in the field of rural tourism, organic production, the supply of indigenous products, and high quality gastronomic offerings, as well as souvenirs from the municipality area as well as entire regions.

There were two fairs in the Travnik municipality, wheregastronomic products were presented. Mountain Vlašić hosted the „Vlašić Expo Tours“ - tourism festival from 2003 to 2013, which marked the beginning of the winter season in this area.Visitors had the opportunity to see the exhibition spacewith tourist supply from all over Bosnia and Herzegovina, but also the offer of representatives of restaurants and winter centers, as well as numerous exhibitors of local specialties, authentic Vlašić products such as Vlašić cheese, honey, herbs and souvenirs of traditional crafts. Until 2011, the International Vlašić Cheese Fair was held 6 times, once a year, with the goal of the promotion of cheese production in Central Bosnia region and beyond, and highlighting the value of the tradition. The event had an exhibition and sales character and, among other things, it wanted to give incentive to the creation of a brand of indigenous and traditional cheeses.The traditional Sheep Pramenka Exhibition and the Vlašić Cheese Fair, which gathers a large number of sheep breeders and cheese producers in the area, have taken on this role today.

The municipality of Novi Travnik has one, already traditional, manifestation "Dani maline"(Raspberry Days). More than 50 growers of raspberries, spices and medicinal herbs and other organic products participated in this international fair of organic production and eco tourism in 2018. Visitors were presented with rich content of organic products, raspberries, berries, honey, various tourist attractions, as well as gastronomic supply.

The exhibition and sale fair of agricultural and food products "Jesen u Visokom" (Autumn in Visoko)has been held in Visoko 14 times already. This fair brings together agricultural producers across Bosnia and Herzegovina with a diverse exhibition program. Smoked meat from Visoko, cheeses and other dairy products, also honey and fruits, vegetables, homemade juices, teas, organic products, agricultural machinery, medicinal and ornamental plants, home-made handicrafts are presented at the fair. Within the fair, a special program, „Gastro offer" of traditional food and drink with educational workshops is held.

Several fairs with gastronomic supplyare organized in Zenica. The one that stands out is The Fair of Organic and Agricultural Production and Ethno Creativity - Opens, with exhibition and sales character. Over 5.000 agricultural products were presented at last year's fair.International Pancake Day in this city is celebrated with the "Everyone loves pancakes" festival. This event brings together a large number of pancake lovers who 
have the opportunity to taste both savory and sweet pancakes, and to enjoy the skills of top chefs in the preparation and serving of these treats. Many food and beverage producers will have the opportunity to showcase their products through promotions and tastings.As a special, distinctive feature of Zenica is the traditional event called "Čimburijada", which is held annually on March 21 on the banks of the river Bosna. On the first day of spring 2018 at this event, promoters and visitors made and tasted "čimbur" - a dish of 1.500 fried eggs.Local authorities and citizens are trying to keep this gastronomic event as a centuries-old tradition in its original form and to register and brand it as a tourist attraction.

In the municipality of Vareš, at the northernentrance to the fortress Bobovac, for the last twoyears the "Bosnian GastroFest on the Royal City of Bobovac" has beenorganized. The event is part of the project "Tradition and Multiculturalism with Respect for Diversity to Better Interethnic Relations in Bosnia and Herzegovina".In addition to the rich Bosnian gastronomic supply, served as traditionally prepared and served throughout history, folk craftsand a competition for the selection of the best prepared dessert (ružice, hurmašice), the event also organizes a competition in traditional folk sports disciplines.

City of Sarajevoadministratively consists of four municipalities: Novi Grad, Novo Sarajevo, Center and Stari Grad. Neighboring municipalities are Vogošća and Ilidža. Due to the exceptional connectivity and proximity of these six municipalities, their gastronomic supply can be seen as the gastronomy of Sarajevo.In addition to a veryrichcateringoffer, there are numerousfairs and festivals in Sarajevo as the administrative, political, cultural and economiccenter of the country, which complement the gastronomicsupply and present the gastronomicspecialties of the area (Table 2).

Table 2: Gastronomic Events in Sarajevo in 2019

\begin{tabular}{|l|l|l|}
\hline Event & Goal of the event & Time period \\
\hline GASTRO - EKO & An event that promotes natural & $17-20$ of April \\
resources, tourist attractions as well as & \\
Food festival - & Bosnia and Herzegovina's cultural \\
sevdahom“ & $\begin{array}{l}\text { heritage; handicrafts, folk costumes, } \\
\text { traditional games and songs and recipes. }\end{array}$ & \\
\hline TEA FEST 2019 & $\begin{array}{l}\text { Presentation of medicinal herbs - raw } \\
\text { material, bee products, equipment for } \\
\text { the production and drying of medicinal }\end{array}$ & $12-16$ of June \\
Herbs Festival & $\begin{array}{l}\text { herbs and bee products, cosmetics based } \\
\text { on medicinal herbs and bee products, } \\
\text { berry products, secondary forest fruits, } \\
\text { mushrooms, and pallet products healthy } \\
\text { organic food. }\end{array}$ & \\
\hline $\begin{array}{l}\text { BEE FEST 2019 } \\
\text { Beekeeping and } \\
\text { Beekeeping } \\
\text { Equipment Festival } \\
\text { products, beekeeping equipment, } \\
\text { presentation of teas. }\end{array}$ & September \\
\hline
\end{tabular}




\begin{tabular}{|c|c|c|}
\hline $\begin{array}{l}\text { SHF - SARAJEVO } \\
\text { HALAL SAJAM } \\
\text { 2019 } \\
\text { 2nd International } \\
\text { Halal Industry Fair }\end{array}$ & $\begin{array}{l}\text { The rich program of the fair, among } \\
\text { other things, enables the promotion of } \\
\text { local halal products, meetings of } \\
\text { regional halal product manufacturers } \\
\text { and halal service providers, as well as } \\
\text { presenting Bosnian food chefs at the fair } \\
\text { presenting food preparation in } \\
\text { accordance with halal standards. }\end{array}$ & $\begin{array}{l}16-28 \text { of } \\
\text { September }\end{array}$ \\
\hline $\begin{array}{l}\text { SARAJEVSKI } \\
\text { SAJAM } \\
\text { TURIZMA } 2019 \\
\text { 41st International } \\
\text { Tourism and } \\
\text { Hospitality Fair }\end{array}$ & $\begin{array}{l}\text { Presentation of domestic and foreign } \\
\text { tourist supply; } \\
\text { promotion of: all forms of tourism, } \\
\text { domestic tourism and natural resources, } \\
\text { domestic and foreign tour operators and } \\
\text { tourism companies; } \\
\text { offer: domestic and foreign tourist } \\
\text { capacities, winter tourist centers in the } \\
\text { country and the region, sea holidays in } \\
\text { country and the region, gastronomic } \\
\text { programs of food and beverages. }\end{array}$ & $\begin{array}{l}09-11 \text { of } \\
\text { October }\end{array}$ \\
\hline $\begin{array}{l}\text { SAJAM } \\
\text { PRIVREDE } 2019 \\
\text { 42nd Consumer } \\
\text { Goods Fair and } 5 . \\
\text { Economy, } \\
\text { Agriculture and } \\
\text { Crafts Fair }\end{array}$ & $\begin{array}{l}\text { Presentation and promotion of: } \\
\text { agricultural products (crop production, } \\
\text { livestock breeding and fishing), food } \\
\text { products (mill and bakery industry, } \\
\text { confectionery industry, oil processing } \\
\text { and production industry, fruit and } \\
\text { vegetable processing industry, dairy } \\
\text { industry, fish canning industry, meat } \\
\text { processing industry and the beverage } \\
\text { industry), consumer goods (cosmetics, } \\
\text { household chemicals, small home } \\
\text { appliances, computers, televisions, } \\
\text { clothing and footwear), old crafts and } \\
\text { handicrafts. }\end{array}$ & $\begin{array}{l}10-12 \text { of } \\
\text { December }\end{array}$ \\
\hline $\begin{array}{l}\text { KUPUJMO } \\
\text { DOMAĆE } 2019 \\
\text { Small Family } \\
\text { Business Fair }\end{array}$ & $\begin{array}{l}\text { To present the products of the local, } \\
\text { Bosnian food industry, organic } \\
\text { production, honey, then the production } \\
\text { of jewelry, handicrafts and cosmetics. In } \\
\text { addition, the fair will feature domestic } \\
\text { companies from various industrial fields } \\
\text { such as textile and construction. }\end{array}$ & $\begin{array}{l}13-16 \text { of March } \\
10-13 \text { of April } \\
16-19 \text { of } \\
\text { October } \\
13-16 \text { of } \\
\text { November }\end{array}$ \\
\hline
\end{tabular}

Source: Kalendar sajmova i manifestacija u Bosni i Hercegovini 2019., Vanjskotrgovinska komora $\mathrm{BiH}^{1}$

\footnotetext{
${ }^{1}$ http://komorabih.ba/vanjskotrgovinska-komora-bosne-i-hercegovine-objavila-kalendarsajmova-u-bih-za-2019-godinu/ - accessed February 12, 2019.
} 
In addition to the previously mentioned gastronomic events, a lot of other festivals and fairs which also have a gastronomic offer, are held in Sarajevo. Thus, in 2018, the first regional fair of gastronomy and catering in BIH called GAST FEST was held.

The fair, featuring all the novelties exclusively for caterers, hoteliers and sommeliers, brought together more than 50 exhibitors from 4 countries in the region. The fair itself featured exhibitors' presentations, cooking shows, and a chefs competition in the preparation of various chicken specialties.Beverage festivals are also specific gastronomic events. For the 12th year in a row, a traditional international event called "Sarajevo Wine Fest" is being organized in Sarajevo. Over 201 exhibitors, the best wine and gastronomic producers from Bosnia and Herzegovina and the region, will participate in the event in 2019. The goal of the Festival is to promote the wine industry and the culture of wine, tourism, catering and expand the gastronomic supply.A similar festival is „Sarajevo Wine Weekend“, one of the largest and most famous Bosnian wine and gastronomic exhibitions. The Sarajevo Beer Festival has been organized in this city for the past seven years. This festival is a beer and gastronomic oasis with premium, lager, wheat and craft beer flavors. A strong craft movement and a culture of enjoying top quality local beers have not omit Bosnia and Herzegovina as well, so many local craft breweries are on offer at the festival.The sixth in a row „Spirit Fest Sarajevo“ the international festival of spirits and brandy, was held in November 2018, when more than 40 exhibitors from Bosnia and Herzegovina and European countries presented their products.During the program, visitors had the opportunity to taste top quality brandy with gastronomic delicacies. In order to preserve the tradition, promotion and placement of authentic products, the festival hosted awards for the best brandy. A total of 118 samples were evaluated in the categories of fruit and grape brandy, specialty brandy and liqueurs.

The City of East Sarajevo covers the area of six municipalities: Istočna Ilidža, Istočno Novo Sarajevo, Pale, Istočni Stari Grad, Sokolac and Trnovo. Mainly sports and cultural events are organized in this area, and gastronomic supply is presented only at some of them. One manifestation called „Jagnjijada“" has been taking place for eight years at Vučija Luka in the municipality of Istočni Stari Grad. The competition in roasting and tasting lambs of this area brings together a large number of teams and participants. Then, Ilindan fest - marking the day of Sokolac municipality - a cultural - sporting event which also includes a gastronomic supply of the area. It is specific, among other things, in the competition for making fish and game kettles. "Tebi goro Romanijo" is a spiritual - cultural - sport - tourist event on mountain Ravna Romania.Following program contents of this event are: Roman Honey and Medicinal Day, Gastro Meet - presentation of traditional local cuisine, with a booth of visiting cultural groups coming from other regions ${ }^{1}$.

The municipality of Višegrad boasts a good tourist presentation and activities carried out by the Tourist Organization of this municipality. In a series of events organized throughout the year, there are several gastronomic events that present traditional dishes and folk art. These activities significantly contribute to the overall tourist presentation of the municipality.The event "Drinski kotlić" (Drina kettle) is held every year in September-The goal of this event is to promote the potential of the Drina River, its banks

${ }^{1}$ https://www.sokolacturizam.net/dokumenti/flajer-manifestacije.pdf - accessed February13, 2019. 
and the richness of fish stocks, as well as the gastronomic supply of Višegrad.The fair of honey and bee products, as well as beekeeping equipment, attended by beekeepers from the region, is of an exhibition and sales character. Products that are presented are based on honey, a mixture of propolis, pollen and honey, followed by honey brandy and various natural energy drinks.,,Zlatne ruke Podrinja“ (Golden Hands of Podrinje) - is a regional event that has been taking place in this area since 2012. The main purpose of the event is to promote traditional folk art, old and forgotten crafts, traditional handicrafts, souvenirs, local agricultural products saved in the traditional way and herbs.,,Višegradska pasuljijada“" (Višegrad Beans Fest) - held for the first time last year, brings together participants from Višegrad and the region, competing to make traditionally the best beans in a kettle on fire.

In the area of Foča municipality there are two already traditional manifestations "Gastro Foča" and "Blueberry Days". Gastro Foča is a festival that has been presenting gastronomic supply, traditional authentic food and drinks from the area of Foča, Višegrad, Rudo, Rogatica, Nevesinje and Trebinje for over a decade. Pastries, pizzerias and restaurants, associations of fishermen, mountaineers and representatives of catering schools are participating and presenting their offers. The offer includes, among others, natural brandy and dried plums, organic production of jam and juices, buckwheat and other cereal products without the use ofchemical substances, as well as goat and sheep's milk cheese. The event is a form of promotion of gastronomy as an important part of the overall tourist supply of this area.Blueberry Days are traditionally held in Foča, but last year, in cooperation with tourism organizations this event took place in Trebinje. Visitors could taste blueberries, juices, jams and other products made from this forest fruit. Blueberry cakes and pies are main products and teas made from herbs from Zelengore are also presented.

The area of the City of Goražde has always been known for the cultivation of traditional fruit varieties and the production of organic food. One of the most famous manifestations is "Dani jabuke" (Apple Days). In addition to apples, other products of fruits and vegetables, jam, juices, honey, nuts, buttermilk, ajvar, sage, various kinds of sweet, wine and brandy could be found as a part of the offer. The traditional 12th Days of Honey and Medicinal herbs were held last year in this city. At the Honey Days Fair, beekeepers and honey producers from Bosnia and Herzegovina, Serbia and Montenegro presented honey and honey products, medicinal and aromatic herbs, flowers and equipment for honey production. The main purpose of the fair is to promote healthy food and traditional products in rural areas. In the area of the City, but also in the municipality of Foča - Ustikolina, the Association of Agricultural Producers organized last year, the 14th traditional event called „Zdrava hrana iz Ustikoline - Ustikolina 2018“ (Healthy Food from Ustikolina). The fair has an exhibition and sales character, and the exhibition featured beekeeping products, fruit and fruit products, vegetable products, milk and dairy products, bakery products, cereal products, meat and meat products, forest products, as well as various handicrafts.

In all these manifestations, food appears as the basic factor, the basic content, the motive for organizing the event itself. Events, in principle, can be tied to a specific product, production technology or processing of a product of particular importance for the area, in this case the Central Bosnia region. The specificity, attractiveness and variety of food and nutrition, the way of preparing these foods, and the need for tourists to try something new, which is specific to a particular area, have caused gastronomy with culinary and 
national diversity to create a special kind of tourism - gastronomic tourism. The goal of gastronomic events is to promote the quality, importance and sales of a particular product, but they are often part of the other forms of tourism - rural, spa tourism or part of various cultural and sporting events. They are often organized during the summer season to enrich the content of tourists' stay, especially in less attractive tourist areas.

\section{DISCUSSION}

\section{State and perspectives of gastronomic tourism development}

Each destination has its own specific characteristics, its own specific customs which are based on national cuisine and gastronomy and their combination makes a quality that tourists can not be immune to.Such events leave a more favorable impression on tourists while raising the qualitative level of the tourist supply of a particular destination, in this case the Central Bosnia region. In addition to manifestations where food appears as a primary motif, there are also fairs and festivals in this region where gastronomy is an accompanying motif, but a very important part of the content of the manifestation in terms of activities. These manifestations can have economic (promotion of products of the construction, mechanical, wood, automotive industry, etc.), production-commercial, educational-cultural or entertaining character, and within them gastronomic products are supporting elements. The announcement of all major events and fairs, regional and international in Bosnia and Herzegovina are available on the website of the Foreign Trade Chamber of Bosnia and Herzegovina.

When it comes to the Central Bosnia region, the presentation of the tourist and gastronomic supply is very complicated and uneven in all its parts, given the already mentioned administrative and political position of the region. Tourist boards in the Federation of Bosnia and Herzegovina were formed on the cantonal level. On the territory of Central Bosnia region tourist boards of following cantons are operating: Central Bosnia, Zenica - Doboj, Sarajevo and Bosnian - Podrinje. Tourist organizations in parts of the regions that belogs to Republika Srpska, were formed at the level of the municipalities of Šipovo, Mrkonjić Grad, Han Pijesak, Sokolac, Rogatica, Višegrad, Foča, Čajnice, Rudo and the City of Istočno Sarajevo. Of the four tourist boards from the territory of the Federation of Bosnia and Herzegovina, only the portal of the Tourist Board of the Zenica-Doboj Canton can boast of its appearance and content, since it provides information on gastronomic supply in rural areas. The portal of the Tourist Board of the Sarajevo Canton, from its scope, presents a large number of all types of catering establishments with their gastronomic supply. Unlike the previously mentioned the tourist boards of the Central Bosnian and Bosnian Podrinje Cantons offer very little information on gastronomic supply and gastronomy of rural areas.

Tourist boards in the territory of Republika Srpska, within the Central Bosnia region, offer on their web portals various contents related to gastronomy presentation for tourism purposes. The best presentation of the gastronomic supply is given by the Tourism Organization of Istočno Sarajevo and the municipality of Višegrad. These two organizations on their portals offer the opportunity to get acquainted with the gastronomic supply and events. Tourist organizations of municipalities such are Čajniče, Han Pijesak, Mrkonjić Grad and Rudo don`t have websites at all. 
When it comes to the official municipal websites, for the whole area of this region, they have no content of tourist and gastronomic supply. The site of Mrkonjić Grad municipality stands out, among other things, it contains a tourist guide with a lot of information on gastronomy and events related to gastronomy.

Preserving the traditions and customs of the local areas in this part of Bosnia and Herzegovina is becoming an integral part of the population's interest. Rural tourism is becoming very important in an effort to share traditions and customs with others and to share the natural and cultural-historical beauties of the local area with as many people as possible. Preserved natural surroundings, escape from the city noise, healthy food made without additives, clean air and vast expanses of mountainous areas near the city centers are just some of the most attractive destinations in rural tourism. Ethno villages as places for relaxation and rest in a rural setting are increasing in the Central Bosnia region. Lately, tourists have also been offered a stay in eco houses or ethno-style households for the purpose of rest and recreation in a natural setting and the offering of traditional, indigenous food.Very popular segments of tourism supply arespa areaswith medical and recreation purposes. In this sense, the need for a more serious and rational attitude towards nutrition is imposed, with a program of natural, balanced nutrition in such destinations. This applies especially to the elderly, patients in the phase of convalescence, but also to healthy persons exposed to excessive stress, psychophysical stress and other adverse environmental factors, then to overweight people and athletes in the preparation and recovery phases. According to Tojagić, Tešanović (2003), for such an approach, nutrition should be organized in 3 directions:

- to expand and modernize the dietary assortment,

- to organize more rationally and attractively the diet of healthy people,

- to promote and use indigenous raw materials more often in the preparation of local specialties.

Thanks to the natural resources in the spa complexes in Fojnica, Olovo, Sarajevo and Kiseljak, capacities for the treatment of various diseases have been developed. Each also requires a specific diet. Quality, health-safe and attractively prepared food could be a significant element and a strong motive for the arrival of guests and the basis for the further development of the tourist supply.

One of the possibilities for the development of gastro tourism is the development of halal tourism, which is becoming increasingly popular. It implies that tourists are satisfied with two needs: providing the conditions for performing religious ceremonies and food prepared according to halal standards. In the last decade, Bosnia and Herzegovina, and even the Central Bosnia region, has become a significant destination for tourists from the Middle East (tourists of Islamic religion). According Halal Journal research Bosnia and Herzegovina ranks fourth in the world's most attractive halal tourism destinations. It is important to align your production with the requirements of the halal standard which sets out the requirements and measures that must be taken to ensure halal quality. The standard specifies what is allowed and what is prohibited under Islamic rules, how to slaughter halal animals, how to label halal products, which are halal additivesa and which are not, and how it certifies and verifies compliance with the provisions of the standard. In accordance with international standards and world best practices and experience, a halal certification system that is compatible with other international standards governing the quality management system (ISO and HACCP) has been built and it is in line with the halal standard of OIC/SMIIC I Islamic 
Conference countries - Halal food. Therefore, it is easy to use in regulated industrial plants. The Halal Standard constitutes a set of rules and guidelines for the production and preparation of food or services in accordance with the rules of Islam. In order for a product to be halal, it must first meet hygiene requirements, be healthy and healthy to eat. In addition to the fact that a specific product does not contain components of porcine origin or alcohol, the halal label also implies that the product does not contain any hormones, genetically modified substances, antibiotics and other toxic ingredients. The Halal Certification Agency points out that in Bosnia and Herzegovina, currently six hotels and three restaurants have a halal certificate, one of which is in Ljubuški and all other facilities are in the Central Bosnia region (City of Sarajevo, Ilidža and Vogošća). There are 28 halal manufacturers in this region ${ }^{1}$. In the Sarajevo Canton, as the most economically important part of both the region and the state, 422.593 tourists arrivals by country of residence were registered during 2017. According to the Federal Bureau of Statistics, most of tourists were from Turkey (62.724), Croatia (39.243) and the United Arab Emirates (25.846). Halal tourism in the Central Bosnia region should move in a systematic direction of development, given the increasing number of tourists coming to this area.

\section{CONCLUSION}

Gastro tourists visit certain areas primarily for tasting food and drink specific to the area. The development of gastronomy in the Central Bosnia region can contribute to the development of its overall tourist supply. The benefits of gastronomy development are reflected in followig:

- the creation of a complete and quality tourist product and the enrichment of the overall tourist supply,

- development of tourism inland and beyond the main tourist season (especially in spring and autumn), and

- the promotion of a unique image of the destination on international level.

In addition to the development of gastronomic tourism, the development of rural areas, the motivation for entrepreneurship, employment and self-employment, culture and traditions, and the marketing of local products for winemakers and farmers are particularly important.

Rural and gastronomic tourism of the Central Bosnia region, although not developed enough, has a great potential. The activities that should be undertaken with the aim of improving the gastronomic supply and the development of gastronomic tourism in this region are following:

- $\quad$ to develop a range of typical gastronomic products, especially from ecologically produced foods,

- to work on preserving local specialties, products and recipes,

- to design thematic gastronomic and culinary events,

- $\quad$ to present gastronomic offerings through domestic airlines offering indigenous specialties and products on the planes,

${ }^{1}$ http://halal.sourcecode.ba/Public/HotelRestaurant - accessed February14, 2019. 
- to organize the harvesting of herbs and forest fruits in rural areas with educational workshops, as well as enabling tourists to participate in the preparation of gastronomic specialties specific to the region.

An especially important step in protecting the region's gastronomic products, which would thus become recognizable at the regional and international levels, is to label indigenous products by geographical origin, originality of food and traditional food appearance. These products also have a developed market both in Europe and in the world, which further indicates the development of this area, especially gastronomic tourism.

\section{LITERATURE}

Babolian Hendijani, R. (2016), Effect of food experience on tourist satisfaction: The case of Indonesia. Int. J. Cult. Tour. Hosp. Res., 10, 272-282.

Bjork, P., Kauppinen-Raisanen, H. (2016), Local food: A source for destination atraction. Int. J. Cont. Hosp. Manag., 28, 177-194.

Drešković, N., Mirić, R. (2017), Regionalna geografija Bosne i Hercegovine I, Prirodno - matematički fakultet Univerziteta u Sarajevu, Sarajevo

Fields, K. (2002), Demand for the gastronomy tourism product. Motivational factors. In Tourism and Gastronomy;Hjalager, A.M., Richards, G., Eds.; Routledge: London, UK, 36-50.

Jiménez-Beltrán, J., Lopez-Guzmán, T., González, F. (2016), Analysis of the Relationship between Tourism and Food Culture. Sustainability, 8, 418.

Kalenjuk,B.,Tešanović, D., Škriljar, M.etal. (2011),Gastronomski potencijali Vojvodine ufunkciji razvoja turizma, Zbomikradova Departmanazageografiju, turizam i hotelijerstvo,br.40,PMFNoviSad, 181

Lakušić, A. (1999), Bosanski kuhar - Tradicionalno kulinarstvo u Bosni i Hercegovini, 7. dopunjeno izdanje, Svjetlost, Sarajevo.

Rinaldi, C. (2017), Food and Gastronomy for Sustainable Place Development: A Multidisciplinary Analysis of Different Theoretical Approaches. Sustainability, 9 (10), 17 - 48. DOI: 10.3390/su9101748.

Tešanović, D., Banjac, M., Kalenjuk, B., Tošić, P. (2018), Identifikacija gastronomskih resursa kao dela kulturnog nasleđa u razradi koncepta održivog razvoja Vojvodine,SITCON, Culture, heritage and tourism development, 186-192, DOI: $10.15308 /$ Sitcon-2018

Tojagić, S., Tešanović, D. (2003), Neka razmišljanja o ishrani u savremenoj turističkoj ponudi, Turizam br. 7, Prirodno-matematički fakultet Departman za geografiju, turizam i hotelijerstvo, Novi Sad, 102.

Stone, M.J., Migacz, S., Wolf, E. (2018), Beyond the journey: The lasting impact of culinary tourism activities. Curr. Issues Tour., 22, 147-152.

Vulić, G. (2006), Model razvoja i promocije gastronomije za potrebe turizma u Sloveniji, Turizam br. 10, Prirodno-matematički fakultet Departman za geografiju, turizam i hotelijerstvo, Novi Sad, 240.

Zaštita izvornosti, geografskog porijekla i tradicionalnog ugleda u prehrambenoj industriji, Northeast regional development association, Tuzla, 2009, 15 
Mrkonjić grad - turistički vodič, Udruženje za razvoj i unaprjeđenje turizma i općine Mrkonjić Grad - Mrkonjička kapa, 2010. 32-34.

\section{Internet sources:}

1. https://www.worldfoodtravel.org/cpages/what-is-food-tourism accessedFebruary06, 2019.

2. https://www.atvbl.com/vijesti/drustvo/vasar-u-mrkonjic-gradu-najbolja-sljivovicaiz-ribnika-24-11-2018 - accessedFebruary 11, 2019.

3. http://komorabih.ba/vanjskotrgovinska-komora-bosne-i-hercegovine-objavilakalendar-sajmova-u-bih-za-2019-godinu/ - accessed February 12, 2019.

4. https://www.sokolacturizam.net/dokumenti/flajer-manifestacije.pdf accessedFebruary 13, 2019.

5. https://www.facebook.com/visegrad24info/photos/-accessedFebruary13, 2019.

6. http://halal.sourcecode.ba/Public/HotelRestaurant - accessedFebruary 14, 2019.

7. Popis stanovništva, domaćinstava/kućanstava i stanova u Bosni i Hercegovini 2013. godine: Konačni rezultati, Federalni zavod za statistiku, Sarajevo, juli 2016. http://fzs.ba/wp-content/uploads/2016/12/Konacni-rezultati-Popisa-2013.pdf acessed February 14, 2019. 